\title{
The specifics of national bilingualism in a multilingual environment
}

\author{
O. L. Rizhniak, V. V. Krasnoschok K. B. Karmazina
}

\author{
Donetsk National Medical University, Kropyvnytskyi, Ukraine \\ Corresponding author. E-mail: vikkrasnoschok@meta.ua
}

Paper received 26.10.19; Accepted for publication 16.11.19.

\section{https://doi.org/10.31174/SEND-Ph2019-211VII62-10}

Abstract. The specifics of the national-Russian bilingualism in a multilingual environment. The article discusses the problems of teaching the linguistic cycle disciplines in medical universities, analyzes the features of national-Ukrainian bilingualism in a multilingual environment, offers some techniques for using such modern innovative teaching methods as different types of integration, information and computer technologies, rating assessment of students' linguistic achievements.

Keywords: bilingualism, bilingualism, diglossia, interference, integration, innovative teaching methods, computer translation.

The study of bilingualism / multilingualism is not a new field of linguistic research. Scientific study of the use of two or more languages in public practice, in everyday life, the study of contact phenomena arising from this, etc. have long been the subject of world science of language.

Some success in the study of interlingual processes and phenomena was achieved even by linguists of the XIX century. - G. Grünbaum, G. Shukhard and others. Then the problem of the mutual influence of the two languages was paid a lot of attention by IA. Baudouin de Courtenay, V.A. Bogoroditsky, E.D. Polivanov, L.V. Scherba. But the interest in research in this area especially increased in the second half of the 20th century after the publication of the monograph "Language Contacts" by W. Weinrach [3]. At the IX International Linguistic Congress, R. Jacobson in his program speech noted: "The study of bilingualism, which for a long time has been underestimated or not considered at all, is gradually becoming one of the central tasks of our science"[2]. For obvious reasons, the issue of national-Russian bilingualism in Ukraine was especially relevant during the Soviet period. This problem was addressed by such well-known linguists as I.K. Whitehead, MA Britcin, G.P. Izhakevich, M.A. Karpenko, V.I. Kononenko, S.V. Semchinsky, T.G. Chertorizhskaya and many others.

In modern linguistics, several terms are simultaneously used to denote such a phenomenon - diglossia and bilingualism. There are different approaches to the interpretation of the values of these items. Originally originated as synonyms ( $\partial в y-, \partial u-, \sigma u-)$, , they gradually acquired certain features in use. Most scholars agree that this issue requires careful study.

As a working definition, let us dwell on the formulation of $\mathrm{W}$. Weinrach "... bilingualism is the practice of alternate use of two languages." [3, c. 22]

Among the main problems of working with foreign students of all specialties, a special place is occupied by the peculiarity of their language adaptation, in many cases complicated by problems of the multilingual environment. Socially forced bilingualism, in which each student is obliged to learn the language (s) of the country of his residence, often does not coincide with the language of instruction. Without dwelling on the political aspect of the problem, we note the Ukrainian-Russian diglossia historically established in Ukraine. This language situation is complicated by the problem of interethnic communication of foreign students in everyday life. As a rule, students of many states - Arabs, Uzbeks, Indians, Moroccans, Pal- estinians, and others - study at international faculties at the same time. The distribution of students into groups depends only on the language of instruction, and not on the students' nationality, which causes certain difficulties in communication between them. Therefore, in addition to the native language (sometimes not coinciding with the state, for example, Arabic + French), the student must know Ukrainian and English (or Russian). For students of some universities, a first-year program provides for the study of Latin - an international language of science (medicine, law, etc.). Thus, instead of the expected bilingualism, each student is forced to use from 3 to 5 languages. Note that we are not talking about linguists and in this case the main function of languages is limited to the sphere of communication and learning. All this causes certain difficulties, including misunderstanding and comic situations, examples of which are quite numerous in the arsenal of each language teacher. For example, the reaction of English-speaking students to the proposal of a Latin teacher Fac simile, the association with the word tooth (зуб) among Arab students, the flour (мука) from Moroccans, confusion during the use of Ukrainian words місто (ср. русск. место), неділя (неделя), вродлива (уродливая), річь (речь), and simply mistakes at the level of the reprise of humorists Нинна Анатольевич уже ушли? Нирки на деревах розкриваються.

It is customary to distinguish between positive and negative aspects of a multilingual situation. It is known that with the simultaneous use of the Russian and Ukrainian languages, a close influence on the learning of each of the two languages has a positive effect. The phonetic, lexical, grammatical affinity of both languages helps in their parallel learning. Students easily transfer their existing knowledge from one language to another, which greatly facilitates learning. The positive influence of an already known language on a new one is called transposition. The transposition should be taken into account both when communicating new information (lat. Transpositio permutation) and in the process of working on speech skills. For example, students do not have to explain what the category of gender, number and case is, which sentences are complex which makes it easier for the teacher to work, pay more attention to other, more complex grammar questions. For example, we consider it a good solution to explain the difference in grammatical structure between synthetic (Russian, Ukrainian, Latin, etc.) and analytical (English, French, Uzbek, etc.). In the case when students are already familiar with the peculiarities of the 
Latin language, the explanation of the grammatical material of the Slavic languages can be begun with the analysis of an example from Latin.

In any case, such integration (lat. Integratio - restoration, renewal) allows students to see the language picture holistically.

On the other hand, it is impossible not to dwell on the problem of unregulated interaction of languages. There are interesting cases of the so-called lexical interference (lat. Inter - between, ferns - introducing) - changing the meaning of words of one language under the influence of another. These changes occur, as a rule, spontaneously and do not depend on the will of the speaker.

It is known that "in every language there is the usual use of words, produced original cliches (standard patterns of use, typical schemes of phrases and syntactic constructions, as well as general models of speech behavior in specific situations), ready formulas, words and phrases words used by the speakers of this language "[5, c. 116].

Currently, there are a large number of definitions of interference. Let us dwell on the interpretation of $\mathrm{W}$. Weinrah, who, by the term of interference, means "those cases of deviations from the norms of each language that occur in the speech of bilingual persons as a result of their familiarity with more than one language, i.e. due to contacts of languages "[3, c. 81]. Note that although interference is possible at all four levels of the language, it is most noticeable at the phonetic and lexical levels. It is precisely in this case that the main attention should be directed when learning a new language.

For example, in the speech of many Turkic-speaking students, there is no distinction between the sounds of $U$ and $b I$, therefore, delicate discrepancies are required in the semantics and pronunciation of pairs of $\kappa л И \kappa-\kappa л Б І \kappa$ (dentistry), бЫл - бИл, etc.

No less interesting are the cases of the erroneous use of various paronyms and homonyms in the speech of foreign students. For example, many foreign students do not see the difference in homographs such as бЕлки and белкИ (in the human body) or homophones (спиД - сnиT). Sometimes such discrepancies arise at the border of interaction between Russian (the language of teaching core subjects) and Ukrainian (the state language of living and communicating in everyday life with local residents and classmates): кишкA (Rus. anatomist intestine) and кІика (Ukr. cat). Also in omoforms of $n A p a-n O p a-n a p A$ and others.

Special constant attention of the teacher and a specially developed system of regular exercises require the practical consolidation of generic differences in the Russian language. Its complete absence in the Uzbek language, the passive representation in Arabic, the binary nature of the clan opposition in English (the absence of neuter gender) is complicated by various ways of its expression in analytical and synthetic languages. In most cases, errors in the coordination of nouns with adjectives, numerals, possessive adjectives, past tense forms, although they are among the strongest in the speech of foreign students, do not affect the assimilation of information: одна зуб, наш группа, боль прошла (complicated by kind of in Russian and Ukrainian languages), etc., however, individual cases require special comment, for example: техник - технич$к а$, премьер - премьера.

Also with the category of the genus - for example 80 $\partial A$ водЫ, род - родБI. There is no need to dwell on all the grammatical subtleties of the category; it suffices to dwell on cases typical of medical texts.

Lexical interference is the most common case of interaction between languages. Separate words penetrate from one language into another constantly, which is associated with the process of inhibition in the cerebral cortex of an individual at the time of reproduction of the corresponding elements of the language, resulting in a state in which instead of the desired word or form of one language, the corresponding word or form of another language occurs. It is well known that terminology is no exception. Such examples are widespread and do not require special commentary, while cases of erroneous use of terms formed by the metaphorical way are of particular interest.

It is well known that the terminological nomination is in continuous contact with the common language nomination, since is a kind of interpretation of the object or phenomenon through the prism of the subjective-objective perception from the one who calls. The fact that terminology as a component of a language develops according to laws inherent to the language as a whole, suggests that the semantic nature of the term does not contradict the presence in it of expressive-emotional layers, and such layers do not deprive the term of its specificity and do not prevent it from performing its main function - to denote a special concept.

Many terms used in medicine are formed in this way. For example, classical examples from anatomy: Atlan, the first cervical spine of the spine, named after the mythical holder of the celestial vault, the Achilles tendon (the most powerful and strong tendon of the human body), Hercules disease (epilepsy), the crown of Venus (syphilic rash on the forehead), sexually transmitted diseases, Adam's apple (Adam's apple) and others. Such metaphoricity indicates a high professional erudition and does not cause situations of misunderstanding or ambiguity.

But there are other more prosaic cases. For example, in the speech of dentists, the names корень, мост, канал, дупло, молочные зубы (root, bridge, canal, hollow, baby teeth, etc.,) cause certain difficulties in mastering and require a special commentary by the teacher. Successful will be the selection of special exercises for their distinction.

Many errors in the speech of foreign students arise as a result of excessive enthusiasm for Internet dictionaries. Without diminishing or disputing the obvious advantages of using the latest computer technology in the study of foreign languages, let us dwell on some of the problems of this natural process.

Thus, the constant use of computer translation leads to the fact that most students do not know how to independently use ordinary dictionaries, determine the grammatical and initial forms of words, basic and figurative meanings, etc. 


\section{ЛИТЕРАТУРА} ках / Г. Д. Арнаудов. - София: Медицина и физкультура, 1964. - 944 c.

2. Бекишева Е. В. Формы языковой репрезентации гносеологических категорий в клинической терминологии [Элекпрезентации гносеологических категорий в клинической терминологии. - Режим доступа:(http://www.dissercat.com/content/formy-yazykovoireprezentatsii-gnoseologicheskikh-kategorii-v-klinicheskoiterminologii)

3. Вайнрах У. Языковые контакты: Состояние и проблемы исследования.- К., ВШ, 1979.

4. Деривационный аспект формирования русской медицинской терминологии на основе латинских терминоэлементов. [Электронный ресурс] // Т.Ф. Извекова,
1. Арнаудов Г. Д. Медицинская терминология на пяти язытронный ресурс] / Е. В. Бекишева // Формы языковой ре-

Е.В.Грищенко, С.Н. Гусева, Г.А. Савватеева // Деривационный аспект формирования русской медицинской терминологии на основе латинских терминоэлементов. Новосибирск, 2013. - Режим доступа: (http://www.ngmu.ru/cozo/mos/article/text_full.php?id=1038 )

5. Основи перекладознавства: Навчальний посібник / За редакцією А.Є. Нямцу - Чернівці: Рута, 2008. - 312 с.

6. Самусев Р.П. Эпонимы в морфологии/ Р.П. Самусев, Н.И. Гончаров. - М.: Медицина, 1989. - 352 с.

7. Энциклопедический словарь медицинских терминов./ Гл. ред. В.И. Покровский. -2-е изд. В 1-м т. 50374 термина. - М.: «Медицина», 2001. - 960 с.

8. Якобсон Р. Итоги Девятого конгресса лингвистов. - «новое в лингвистике»; вып. 4, М, 1965, с. 581.

\section{REFERENCES}

1. Arnaudov G. D. Medicinskaja terminologija na pjati jazykah / G. D. Arnaudov. - Sofija: Medicina i fizkul'tura, 1964. $944 \mathrm{~s}$.

2. Bekisheva E. V. Formy jazykovoj reprezentacii gnoseologicheskih kategorij $\mathrm{V}$ klinicheskoj terminologii [Jelektronnyj resurs] / E. V. Bekisheva // Formy jazykovoj reprezentacii gnoseologicheskih kategorij $\mathrm{v}$ klinicheskoj terminologii. - $\quad$ Rezhim dostupa: (http://www.dissercat.com/content/formy-yazykovoireprezentatsii-gnoseologicheskikh-kategorii-v-klinicheskoiterminologii)

3. Vajnrah U. Jazykovye kontakty: Sostojanie i problemy issledovanija.- K., VSh, 1979.

4. Derivacionnyj aspekt formirovanija russkoj medicinskoj terminologii na osnove latinskih terminojelementov. [Jelektronnyj resurs] // T.F. Izvekova, E.V.Grishhenko, S.N.
Guseva, G.A. Savvateeva // Derivacionnyj aspekt formirovanija russkoj medicinskoj terminologii na osnove latinskih terminojelementov. -Novosibirsk, 2013. Rezhim dostupa: (http://www.ngmu.ru/cozo/mos/article/text_full.php?id=1038 ).

5. Osnovi perekladoznavstva: Navchal'nij posibnik / Za redakcieju A.E. Njamcu - Chernivci: Ruta, 2008. - $312 \mathrm{~s}$.

6. Samusev R.P. Jeponimy v morfologii/ R.P. Samusev, N.I. Goncharov. - M.: Medicina, 1989. - $352 \mathrm{~s}$.

7. Jenciklopedicheskij slovar' medicinskih terminov./ Gl. red. V.I. Pokrovskij. -2-e izd. V 1-m t. 50374 termina. - M.: «Medicina», 2001. - $960 \mathrm{~s}$.

8. Jakobson R. Itogi Devjatogo kongressa lingvistov. - «novoe v lingvistike»; vyp. 4, M, 1965, s. 581 